\title{
Effect of regeneration temperature on adsorption equilibria and mass diffusivity of zeolite $13 \mathrm{x}$-water pair
}

\author{
Şefika Çağla Sayılgan ${ }^{a,}{ }^{*}$, Moghtada Mobedi ${ }^{b}$, Semra Ülkü a \\ a Chemical Engineering Department, Izmir Institute of Technology, Urla, 35430, Izmir, Turkey \\ ${ }^{\mathrm{b}}$ Mechanical Engineering Department, Izmir Institute of Technology, Urla, 35430, Izmir, Turkey
}

\section{A R T I C L E I N F O}

\section{Article history:}

Received 4 August 2015

Received in revised form

22 October 2015

Accepted 29 October 2015

Available online 14 November 2015

\section{Keywords:}

Adsorption

Zeolite 13X-water

Adsorption equilibrium

Adsorption kinetics

Regeneration

\begin{abstract}
A B S T R A C T
The adsorption equilibrium and mass diffusivity of zeolite 13X-water pair for different adsorption and regeneration temperatures were determined by a homemade volumetric system. The isotherms of the zeolite $13 \mathrm{X}$-water pair were obtained by collecting pressure versus time data and applying ideal gas law. The effective diffusivity of the pair was calculated by using long term analytical solution of mass diffusivity based on Fick's law.

The experimental study showed that the adsorption capacity of zeolite $13 \mathrm{X}$-water pair was $23 \%$ ( $\mathrm{kg}$ / $\mathrm{kg}), 21 \%(\mathrm{~kg} / \mathrm{kg})$ and $19 \%(\mathrm{~kg} / \mathrm{kg})$ when the adsorption temperature was 35,45 and $60{ }^{\circ} \mathrm{C}$ respectively for the desorption temperature of $90{ }^{\circ} \mathrm{C}$. Furthermore, the adsorption capacity increased from $22 \%(\mathrm{~kg} / \mathrm{kg})$ to $24 \%(\mathrm{~kg} / \mathrm{kg})$ when the desorption temperature was increased from $90{ }^{\circ} \mathrm{C}$ to $150{ }^{\circ} \mathrm{C}$. It was observed that the present adsorption equilibrium results were compatible with the reported results in the literature.

The mass diffusivity of the pair was found in the range of $4 \times 10^{-9}-6 \times 10^{-8} \mathrm{~m}^{2} / \mathrm{s}$ for the long time period when the initial adsorptive pressure was $2000 \mathrm{~Pa}$. The effective mass diffusivity depends on concentration and it was decreased with increasing adsorbate concentration.
\end{abstract}

(c) 2015 Elsevier Inc. All rights reserved.

\section{Introduction}

Adsorption is a surface phenomenon which occurs at fluid-solid interface due to the molecular or atomic interactions. According to the interactions between adsorbate and adsorbent, adsorption can be classified as physical adsorption (physisorption) and chemical adsorption (chemisorption). While electrons are shared and new chemical compound is formed in chemisorption process, the weak intermolecular forces such as Van der Waals, Hbonds, dipole-dipole interactions are generally effective in physisorption processes. Adsorption has large application in various areas from daily life to industrial technology, such as, waste water treatment, drying processes, catalytic reactions and medical applications. In recent years, the use of adsorption in heat recovery and thermal storage systems has gained attention of researchers. The development and use of devices such as adsorption heat pump, adsorption chiller, desiccant cooling system, and adsorption

\footnotetext{
* Corresponding author.

E-mail address: sefikagundogan@iyte.edu.tr (Ş.Ç. Sayılgan).
}

based solar refrigerator show the importance of adsorption technology in energy sector.

In industrial application of adsorption, the selection of an appropriate adsorbent for a particular adsorbate is the most important task. The affinity of the pairs to each other, shape of isotherm, adsorption capacity, heat of adsorption and mass transfer diffusivity of the adsorbate through the adsorbent are the important parameters that affect the selection of the working pair. Zeolites are used as adsorbent and ion exchanger in several industrial applications such as drying processes, water treatment and softening, agriculture and animal husbandry, mining and metallurgy, construction, and started to be used at energy recovery and storage systems [1]. There exist more than 50 natural zeolites and about 150 types of synthetic zeolites named by one letter or a group of letters such as $4 \mathrm{~A}, 13 \mathrm{X}$ and $5 \mathrm{~A}$. Zeolites have high affinity to various gases such as $\mathrm{CO}_{2}$ and water vapor, and the cationic sites in the structure of the zeolites are effective in the adsorption properties of them. High affinity of zeolite for water has a special value since preadsorbed water affects the application of zeolite as catalysis and in separation processes.

In the kinetics studies of zeolites with different adsorbates, concentration dependence of mass diffusivity was usually observed 
[2-5]. Regeneration of zeolites is generally accomplished at temperatures above $350{ }^{\circ} \mathrm{C}$ under vacuum with pressure less than about $0.13 \mathrm{~Pa}$ and requires attention due to the poor hydrothermal stability of aluminum-rich zeolites at high temperatures [5-7]. Ruthven [5] reevaluated his previous studies on the adsorption of propane and n-butane in zeolite $5 \mathrm{~A}$. He stated that the regeneration procedure greatly influences the uptake rate and diffusion coefficient. Even, controlling resistance can be changed from intraparticle diffusion to surface resistance control. Karger and Ruthven [4] explained the unusual pattern of concentration dependence of diffusivity, which was resulted from the increasing significance of heat transfer resistance at higher concentration levels, of $\mathrm{X}$ and $\mathrm{Y}$ zeolites.

Although pre-adsorbed water is effective in adsorption properties, studies related to water adsorption by zeolite are limited and results of these studies are not consistent [2,3,8-17]. Most of the researchers found type I isotherm for zeolite-water pair. However, Ryu et al. [13] obtained type II isotherm for this pair which may be resulted from the ineffective regeneration of zeolite. Gorbach et al. [15] studied the adsorption of zeolite 4A-water pair and observed that the parameters were well fitted with type I isotherm. However, when they analyzed their equilibrium data for lower pressures, the shape of isotherm became type IV isotherm. Özkan [2] and, Özkan and Ülkü [3] performed a study on clinoptilolite-water pair and found that the diffusivity decreased with the increasing adsorbate concentration at the linear part of the isotherm.

High adsorption capacity of the zeolites for water even at low concentrations makes them suitable for dehumidification or storage (or recovery) of energy.

As it can be seen from the previous studies, the number of studies on kinetics of zeolite-water (particularly zeolite 13X-water) is limited and discussions on mass diffusion controlling mechanism and its dependency on concentration still continues. The aim of the present study is to determine the adsorption equilibrium and mass diffusivity of zeolite $13 \mathrm{X}$-water pair experimentally at different operating conditions by a homemade volumetric system. The study focused on the effect of regeneration temperature on the isotherm and kinetics of zeolite 13X-water water pair.

\subsection{Diffusion and kinetic models}

In general, the adsorption rate is controlled by mass and heat transfer resistances. The diffusion of an adsorptive molecule consists of two main steps: diffusion outside the particle and diffusion inside the particle. Bulk, fluid film surrounding the particle and the intraparticle diffusion are effective in the process. One or more than one related resistance may control the mechanism of adsorption rate. However, an additional resistance, skin (surface) resistance, which may be resulted from the constriction of the pore mouth, blockage of the large pores or the hydration and migration of the cations in the structure of the zeolites, has gained the attention of researchers in recent years $[5,18]$. In the calculation of intraparticle diffusion coefficient for an adsorbent-adsorbate pair, several models were developed by considering the shape of isotherm, pore structure of adsorbent particle and experimental setup (finite and infinite volume). With the assumptions of.

- Isothermal system

- Spherical particle

- Constant initial concentration of adsorbate in the fluid

- Independency of the uptake rate from the particle size

- Infinite system volumeone of the well-known analytical solution of the mass transfer equation, based on Fick's law, can be given by; $\frac{\mathrm{m}_{\mathrm{t}}}{\mathrm{m}_{\infty}}=\frac{\overline{\mathrm{q}}-\mathrm{q}_{0}}{\mathrm{q}_{\infty}-\mathrm{q}_{0}}=1-\frac{6}{\pi^{2}} \sum_{\mathrm{n}=1}^{\infty} \frac{1}{\mathrm{n}^{2}} \exp \left(-\frac{\mathrm{n}^{2} \pi^{2} \mathrm{D}_{\mathrm{c}} \mathrm{t}}{\mathrm{r}_{\mathrm{c}}^{2}}\right)$

Effective diffusivity for a particle can also be calculated by using particle radius $\left(R_{p}\right)$ instead of crystal radius $\left(r_{c}\right)[2,19,20]$;

$\frac{\mathrm{m}_{\mathrm{t}}}{\mathrm{m}_{\infty}}=\frac{\overline{\mathrm{q}}-\mathrm{q}_{0}}{\mathrm{q}_{\infty}-\mathrm{q}_{0}}=1-\frac{6}{\pi^{2}} \sum_{\mathrm{n}=1}^{\infty} \frac{1}{\mathrm{n}^{2}} \exp \left(-\frac{\mathrm{n}^{2} \pi^{2} \mathrm{D}_{\mathrm{eff}} \mathrm{t}}{R_{p}^{2}}\right)$

In the long time period, Eq. (1b) can be simplified into the form of Eq. (2).

$\frac{\mathrm{m}_{\mathrm{t}}}{\mathrm{m}_{\infty}}=1-\frac{6}{\pi^{2}} \exp \left(-\frac{\pi^{2} \mathrm{D}_{\mathrm{eff}} \mathrm{t}}{R_{\mathrm{p}}^{2}}\right)$

In the short time period (initial region), Eq. (1b) can also be simplified by Eq. (3).

$\frac{\mathrm{m}_{\mathrm{t}}}{\mathrm{m}_{\infty}}=6\left(\frac{\mathrm{D}_{\mathrm{eff}} \mathrm{t}}{R_{p}^{2}}\right)^{1 / 2}$

For surface mass transfer resistance a similar solution can be represented by Eq. (4). In order to distinguish the difference between intraparticle diffusion and skin resistance to mass transfer, $\ln \left(1-\mathrm{mt} / \mathrm{m}_{\infty}\right)$ versus $\mathrm{t}$ graph is plotted. If the plot passes through the origin, it indicates that mass transfer through the adsorbent particle is controlled by surface resistance. However, the intraparticle diffusion resistance is the main mass transfer controlling mechanism, if the line passes at an intercept of $\ln \left(6 / \pi^{2}\right)$.

$\frac{\bar{q}}{q_{\infty}}=1-\exp \left[-\frac{3 k_{s} t}{R_{p}}\right]$

On the other hand, the assumption of constant boundary condition is valid when the uptake within the particle is too small compared to the adsorption capacity of the system. This situation requires large system volume. Thus, when the system volume is limited, the analytical solution of the mass transfer equation can by determined by Eq. (5) derived for the case of Henry's equilibrium relationship (i.e, $\mathrm{q}_{\infty}=\mathrm{KC}$ or $\mathrm{q}_{\infty}=\mathrm{KP}$ for isothermal case) is valid [21].

$\frac{\mathrm{m}_{\mathrm{t}}}{\mathrm{m}_{\infty}}=1-6 \sum_{\mathrm{n}=1}^{\infty} \frac{\lambda(1+\lambda) \exp \left(-D_{c} \mathrm{q}_{\mathrm{n}}^{2} \mathrm{t} / r_{\mathrm{c}}^{2}\right)}{9(1+\lambda)+\lambda^{2} q_{n}^{2}}$

Where $\mathrm{q}_{\mathrm{n}}$ is given by the non-zero root of following equation:

$\operatorname{tanq} q_{n}=\frac{3 q_{n}}{3+\lambda q_{n}^{2}}$

$\lambda$ is the ratio of the adsorptive concentration (i.e. pressure) to the adsorbate concentration on the solid surface between the initial to final steps of a pulse and can be given as:

$\lambda=\frac{\mathrm{P}_{\infty}-\mathrm{P}_{1}}{\mathrm{P}_{2}-\mathrm{P}_{\infty}}$

Where $\mathrm{P}_{1}$ is the initial pressure $(t<0), \mathrm{P}_{2}$ is the adsorptive pressure at $t=0$ and $P_{\infty}$ is the pressure when $t=\infty$. When the initial and adsorptive pressures at $\mathrm{t}=0$ are equal, the value of $\lambda$ becomes zero. That's the system behaves like infinite system and Eq. (1) will be valid to analyze the adsorption process. 
Table 1

Textural properties of zeolite $13 \mathrm{X}$.

\begin{tabular}{lc}
\hline Property & Zeolite $13 \mathrm{X}$ \\
\hline Single point surface area $\left(\mathrm{m}^{2} / \mathrm{g}\right)$ & 655 \\
BET surface area $\left(\mathrm{m}^{2} / \mathrm{g}\right)$ & 643 \\
Langmuir surface $\mathrm{area}\left(\mathrm{m}^{2} / \mathrm{g}\right)$ & 942 \\
Micropore area $\left(\mathrm{m}^{2} / \mathrm{g}\right)$ & 602 \\
External surface area $\left(\mathrm{m}^{2} / \mathrm{g}\right)$ & 41 \\
Single point total volume $\left(\mathrm{cm}^{3} / \mathrm{g}\right)$ & 0.29 \\
Micropore volume $\left(\mathrm{cm}^{3} / \mathrm{g}\right)$ & 0.31 \\
Average pore diameter $(4 \mathrm{~V} / \mathrm{A}$ by BET $)(\AA)$ & 17.75 \\
Maximum pore volume $(\mathrm{HK}$ model $)\left(\mathrm{cm}^{3} / \mathrm{g}\right)$ & 0.33 \\
Median pore diameter $(\AA)$ & 6.05 \\
Micropore surface area $(\mathrm{D}-\mathrm{A}$ model $)$ & 1335 \\
Limiting micropore volume $(\mathrm{D}-\mathrm{A}$ model $)\left(\mathrm{cm}^{3} / \mathrm{g}\right)$ & 0.35 \\
Mean equivalent pore diameter $(\mathrm{D}-\mathrm{A})(\AA)$ & 10.41 \\
\hline
\end{tabular}

\section{Materials and methods}

In this study, zeolite $13 \mathrm{X}$ and water were used as working pair. The zeolite 13X particles were supplied from Sigma-Aldrich Co. with a particle size of $2.38-4.76 \mathrm{~mm}$. The textural properties of zeolite 13X (Table 1 ) were analyzed by a static volumetric adsorption instrument (ASAP 2010M, Micromeritics Instrument Corporation). The analyses were conducted by $\mathrm{N}_{2}$ at its normal boiling temperature of $-196{ }^{\circ} \mathrm{C}$. The sample was degassed at $300{ }^{\circ} \mathrm{C}$ for $24 \mathrm{~h}$ under vacuum pressure of $10^{-3} \mathrm{~Pa}$.

Thermogravimetric analysis (TGA) of zeolite $13 \mathrm{X}$ was performed by thermal gravimetric analyzer (Shimadzu TGA-51). The analyze of the adsorbent was carried out at a heating rate of $5^{\circ} \mathrm{C} / \mathrm{min}$, under $40 \mathrm{~mL} / \mathrm{min} \mathrm{N}_{2}$ flow up to temperature of $1000{ }^{\circ} \mathrm{C}$.

\subsection{Experimental study}

A volumetric homemade system, shown in Fig. 1, was constructed in order to find adsorption isotherm and diffusivity coefficient for zeolite $13 \mathrm{X}$-water pair.

As seen in Fig. 1, the system consisted of a liquid vessel (Vessel 1) and a vapor vessel (vessel 2) with the volume of $500 \mathrm{~mL}$ and an adsorbent vessel (vessel 3) with a volume of $50 \mathrm{~mL}$. The flow of adsorptive between the vessels was controlled by the manual valves. Vessel 2 and the pipes were heated by the electrical heating cords while an electrical screw clamp heater covered the lateral surface of the adsorbent vessel to achieve uniform temperatures. The pressure of the system was measured by a MKS Series 902P vacuum transducer connected to the pipe above of vessel 2. In addition, Digi Sense Scanning Thermometer was used for temperature logging.

Before starting the adsorption experiments, the system was regenerated for a week at the desired regeneration temperature under vacuum. Thereafter, the temperature of the system was reduced to the adsorption temperature while the evacuation continued. When the thermal equilibrium in the system was reached, the evacuation was stopped and adsorption experiments were started. Differential uptake experiments were performed with successive constant or varying initial adsorptive pressure runs. The adsorptive input was provided by opening valve 1 (V1) and sending water vapor from liquid vessel to the vapor vessel till the desired adsorptive pressure was reached, thereafter V1 was closed, valve 3 (V3) was opened and the adsorptive pressure change was followed for the achievement of the equilibrium. This procedure was repeated until the maximum adsorbent capacity was reached. The adsorptive pressure data against time for successive runs was collected during the experiment.

The adsorption and regeneration temperatures and the initial adsorptive pressures of the successive runs for the performed experiments are given in Table 2. The experiments were performed for constant initial adsorptive concentration and varying initial adsorptive concentration for successive runs. The pressure data was collected for $1 \mathrm{~s}$ intervals. Additionally, the temperature data was also checked with 5 min time intervals.

\section{Results and discussion}

\subsection{Thermogravimetric analyze}

From the TGA results (Fig. 2), it is seen that the dehydration occurs in three steps which is related to the water molecules in

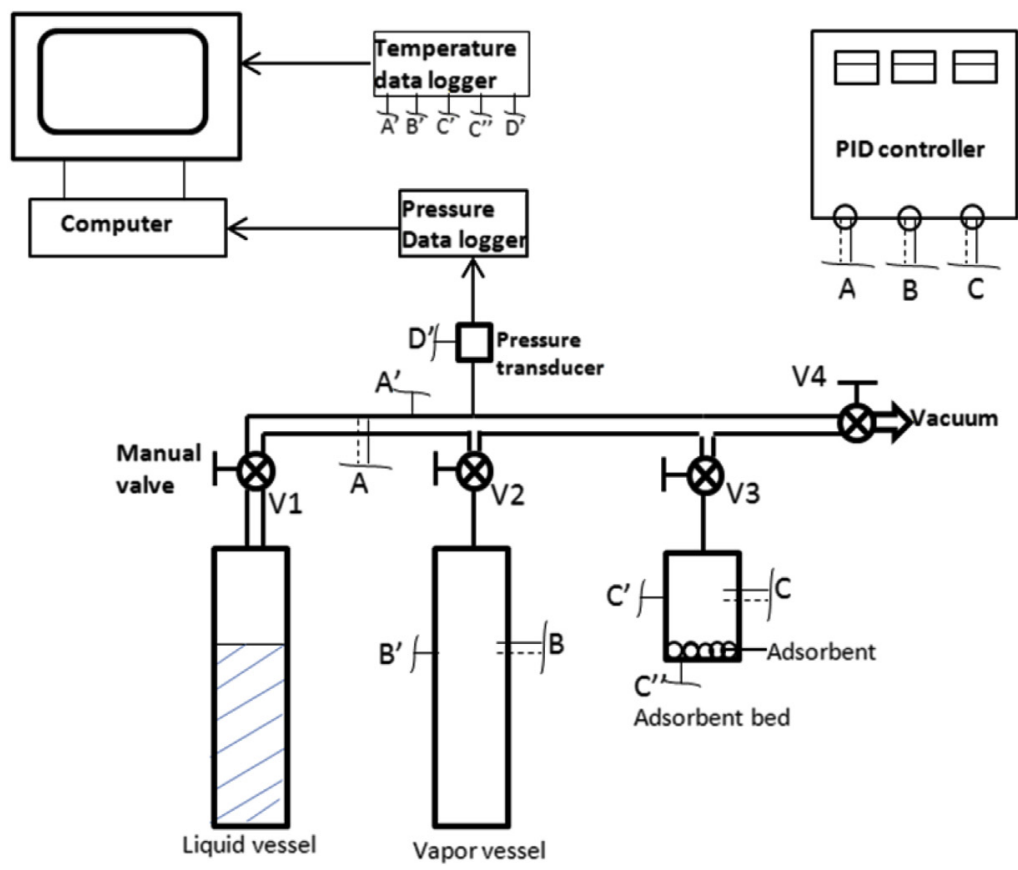

Fig. 1. Schematic view of experimental setup for zeolite $13 \mathrm{X}$-water pair. 
Table 2

Performed experiments.

\begin{tabular}{lll}
\hline $\begin{array}{l}\text { Desorption } \\
\text { temperature }\left({ }^{\circ} \mathrm{C}\right)\end{array}$ & $\begin{array}{l}\text { Adsorption } \\
\text { temperature }\left({ }^{\circ} \mathrm{C}\right)\end{array}$ & $\begin{array}{l}\text { Initial adsorptive pressure } \\
\text { for successive runs }(\mathrm{Pa})\end{array}$ \\
\hline 90 & 35 & $900-5000$ \\
& & 2000 \\
& 45 & $700-6000$ \\
& 60 & $500-5000$ \\
120 & 35 & $500-5000$ \\
& & 2000 \\
150 & & $500-4000$ \\
& & 2000 \\
\hline
\end{tabular}

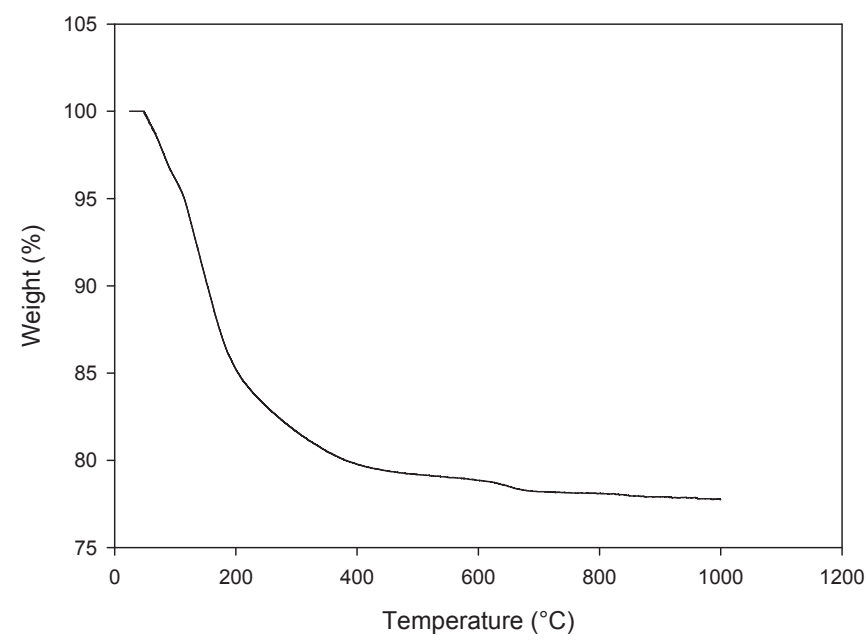

Fig. 2. TGA curve of zeolite $13 \mathrm{X}$.

zeolite are held with a range of energies dependent on the cationwater bond distances and on the exchangeable cation site [22]. Due to the desorption of externally bound water, the first inflection point was observed at $\approx 80{ }^{\circ} \mathrm{C}$. Other inflection point was detected at about $\approx 140{ }^{\circ} \mathrm{C}$ and assigned to desorption of loosely bound water. Above $\approx 140{ }^{\circ} \mathrm{C}$, slow desorption of tightly bound water takes place. The complete removal of water vapor from zeolite $13 \mathrm{X}$ was observed at 115 th $\min$ at $600{ }^{\circ} \mathrm{C}$. In addition, there was an interruption in the TGA curve which led to the deterioration in the framework of the zeolite $13 \mathrm{X}$ at $630{ }^{\circ} \mathrm{C}$. However, it should be noted that not only regeneration temperature and regeneration time, vacuum level is also important for effective regeneration.

\subsection{Adsorption equilibrium of zeolite $13 X$-water pair}

The representative graphs for constant initial adsorptive pressure of $2000 \mathrm{~Pa}$ and varying initial adsorptive pressure at adsorption temperature of $35{ }^{\circ} \mathrm{C}$ are presented in Figs. 3 and 4, respectively. While 22 successive runs were shown in Fig. 3 and 19 successive runs were presented in Fig. 4.

The amount of the adsorbed water was calculated by using the ideal gas law (Eq (8)) and the adsorption isotherms were obtained at different temperatures. The effect of adsorption temperature on adsorption capacity is shown in Fig. 5. The adsorption capacity of zeolite $13 \mathrm{X}$-water pair, regenerated at $90{ }^{\circ} \mathrm{C}$, was $23 \%(\mathrm{~kg} / \mathrm{kg}), 21 \%$ $(\mathrm{kg} / \mathrm{kg})$ and $19 \%(\mathrm{~kg} / \mathrm{kg})$ for the adsorption temperatures $35{ }^{\circ} \mathrm{C}$, $45^{\circ} \mathrm{C}$ and $60{ }^{\circ} \mathrm{C}$, respectively at the adsorptive pressure of $1500 \mathrm{~Pa}$ (see also Table 3).

$\mathrm{PV}=\mathrm{mRT}$

The equilibrium data were analyzed by using the linear form of Langmuir relationship given in Eq. (9).

$\mathrm{q}=\mathrm{q}_{\mathrm{m}}^{\mathrm{sat}} \frac{\mathrm{b}\left(\mathrm{P} / \mathrm{P}^{\mathrm{sat}}\right)}{\left(\mathrm{P} / \mathrm{P}^{\mathrm{sat}}\right)}$

The adsorption equilibria is also presented by the plot of $\mathrm{P} / \mathrm{P}^{\text {sat }}$ versus amount of water vapor adsorbed on zeolite $13 \mathrm{X}$ (Fig. 6). It is seen that the isotherms are overlapped as also indicated by Leppäjärvi et al. [23], where the temperature dependency of the adsorption equilibria was represented by using saturation pressure especially for water adsorption on zeolites. This arised from the independency of the saturation capacity, $\mathrm{q}_{\mathrm{m}}^{\mathrm{sat}}$, from the temperature and constant the dimensionless parameter $n$, which relates to the heterogeneity of the surface, for the adsorbate-adsorbent pair at different temperatures. By means of Fig. 6, the adsorption capacity of zeolite $13 \mathrm{X}$-water pair at $25^{\circ} \mathrm{C}$ was found $24 \%(\mathrm{~kg} / \mathrm{kg})$ at $1500 \mathrm{~Pa}$.

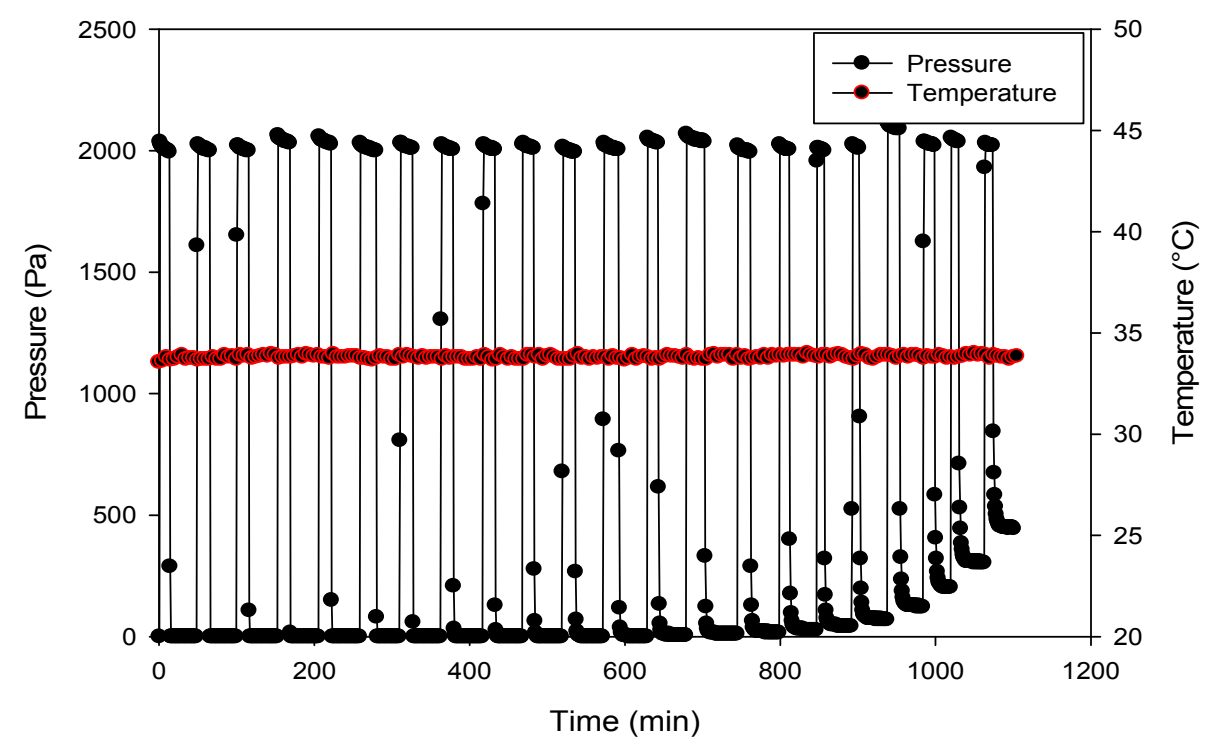

Fig. 3. Representative diagram for pressure and temperature change of zeolite $13 \mathrm{X}$-water pair (Initial adsorptive pressure $=2000 \mathrm{~Pa}$, $\mathrm{T}_{\text {reg }}=90{ }^{\circ} \mathrm{C}$ ). 


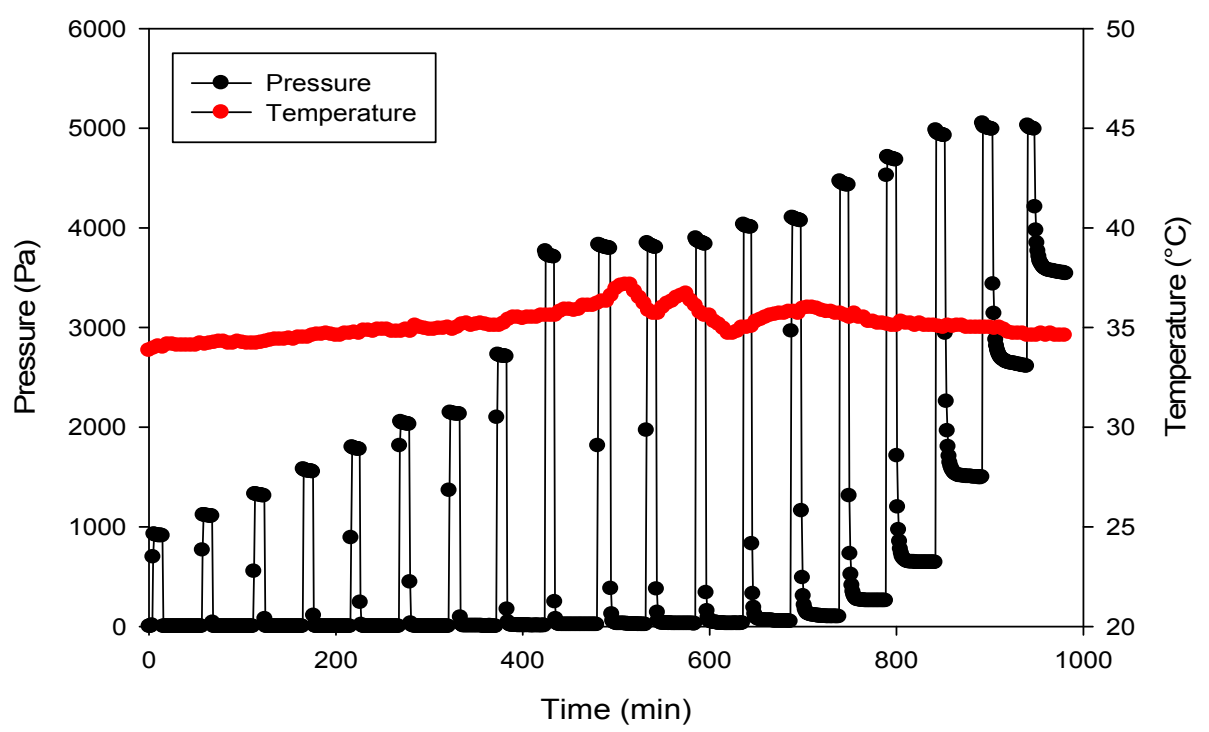

Fig. 4. Representative diagram for pressure and temperature change of zeolite $13 \mathrm{X}$-water pair $\left(\right.$ Varying initial adsorptive pressure, $\mathrm{T}_{\text {reg }}=90{ }^{\circ} \mathrm{C}$ ).

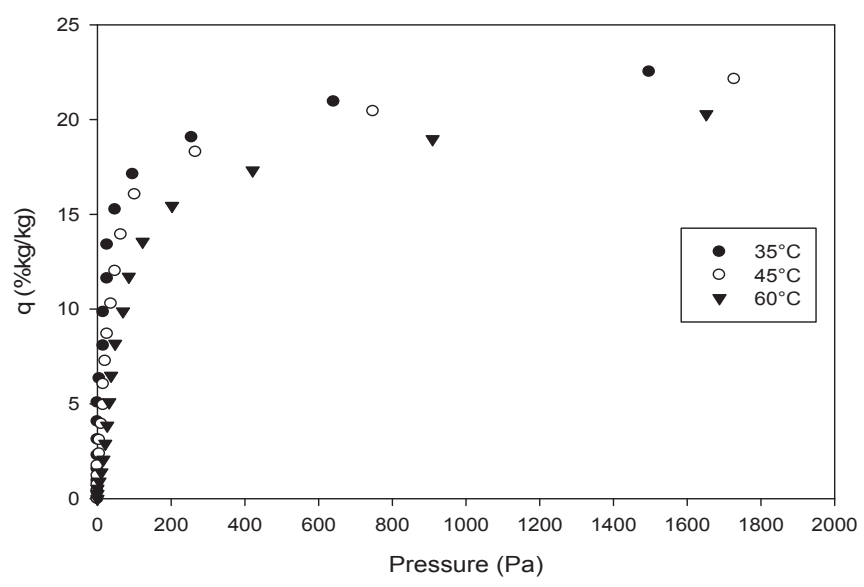

Fig. 5. Adsorption isotherms at different adsorption temperatures $\left(\mathrm{T}_{\text {reg }}=90^{\circ} \mathrm{C}\right)$.

Table 3

Experimental results for zeolite $13 \mathrm{X}$-water pair (*at equilibrium adsorptive pressure of $1000 \mathrm{~Pa})$.

\begin{tabular}{|c|c|c|c|c|}
\hline $\begin{array}{l}\text { Desorption } \\
\text { temperature } \\
\left({ }^{\circ} \mathrm{C}\right)\end{array}$ & $\begin{array}{l}\text { Adsorption } \\
\text { temperature }\left({ }^{\circ} \mathrm{C}\right)\end{array}$ & $\begin{array}{l}\text { Maximum } \\
\text { adsorption } \\
\text { capacity* } \\
(\% \mathrm{~kg} / \mathrm{kg})\end{array}$ & $\begin{array}{l}\text { Initial } \\
\text { adsorptive } \\
\text { pressure for } \\
\text { successive } \\
\text { runs }(\mathrm{Pa})\end{array}$ & $\begin{array}{l}\text { Effective } \\
\text { diffusivity } \\
\text { coefficient } \\
\left(\mathrm{m}^{2} / \mathrm{s}\right)\end{array}$ \\
\hline \multirow[t]{4}{*}{90} & 35 & 22 & $900-5000$ & $\begin{array}{l}1.02 * 10^{-8} \text { to } \\
7.43^{*} 10^{-10}\end{array}$ \\
\hline & & & 2000 & $\begin{array}{l}9.86^{*} 10^{-9} \text { to } \\
2.04 * 10^{-9}\end{array}$ \\
\hline & 45 & 21 & $700-6000$ & $\begin{array}{l}4.36^{*} 10^{-9} \text { to } \\
1.32^{*} 10^{-9}\end{array}$ \\
\hline & 60 & 19 & $500-5000$ & $\begin{array}{l}6.46^{*} 10^{-9} \text { to } \\
1.36^{*} 10^{-9}\end{array}$ \\
\hline \multirow[t]{2}{*}{120} & 35 & 23 & $500-5000$ & $\begin{array}{l}7.11^{*} 10^{-9} \text { to } \\
7.43^{*} 10^{-10}\end{array}$ \\
\hline & & & 2000 & $\begin{array}{l}1.23^{*} 10^{-8} \text { to } \\
2.65^{*} 10^{-9}\end{array}$ \\
\hline \multirow[t]{2}{*}{150} & & 24 & $500-4000$ & $\begin{array}{l}8.34^{*} 10^{-9} \text { to } \\
1.29 * 10^{-9}\end{array}$ \\
\hline & & & 2000 & $\begin{array}{l}5.69^{*} 10^{-8} \text { to } \\
3.07^{*} 10^{-9}\end{array}$ \\
\hline
\end{tabular}

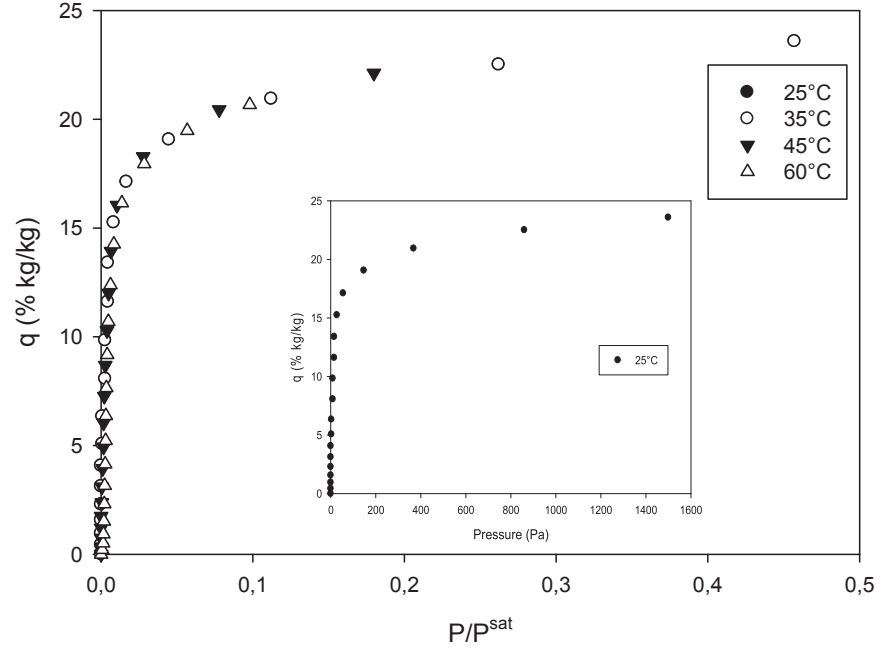

Fig. 6. Adsorption isotherms of zeolite $13 \mathrm{X}$-water pair as a function of $\mathrm{P} / \mathrm{P}^{\mathrm{sat}}$ $\left(\mathrm{T}_{\text {reg }}=90^{\circ} \mathrm{C}\right)$.

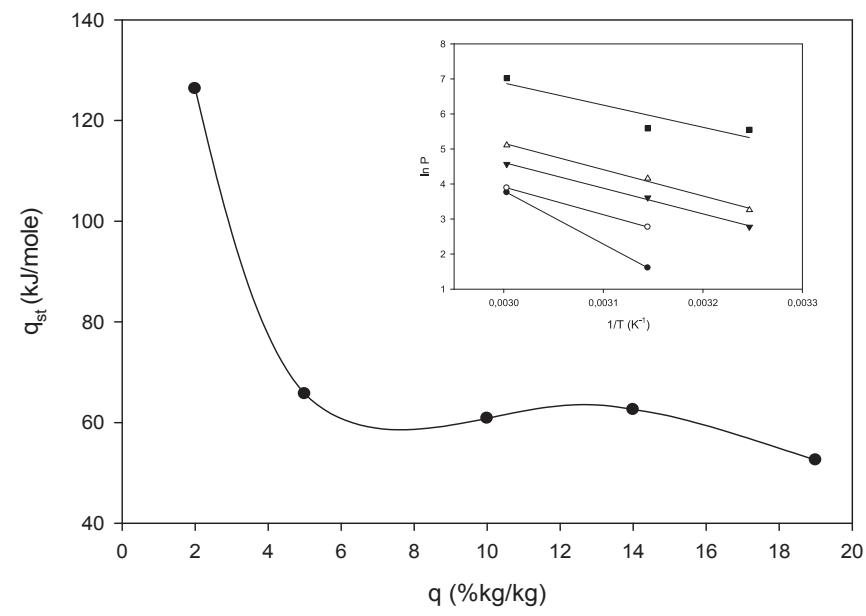

Fig. 7. Isosteric heat of adsorption for zeolite $13 \mathrm{X}$-water pair $\left(\mathrm{T}_{\text {reg }}=90^{\circ} \mathrm{C}\right)$. 


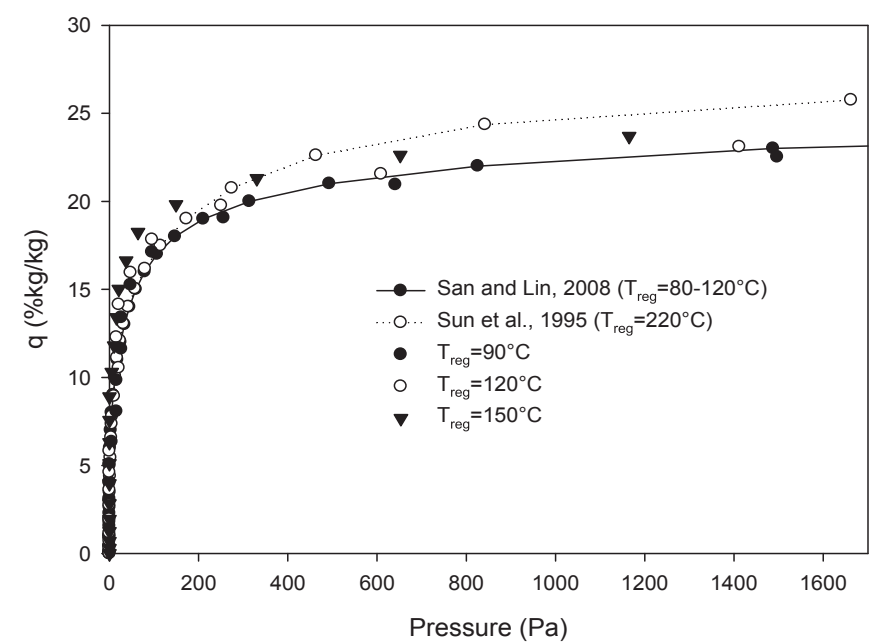

Fig. 8. Adsorption isotherms of zeolite $13 \mathrm{X}$-water pair at $35{ }^{\circ} \mathrm{C}$ for different regeneration temperatures.

The isosteric heat of adsorption of zeolite 13X-water pair which was regenerated at $90{ }^{\circ} \mathrm{C}$ (Fig. 7) was calculated by using Clausius-Clapeyron diagram for the adsorbate concentrations of 2, 5 , 10,14 and $19(\% \mathrm{~kg} / \mathrm{kg})$. The slope of LnP versus $-1 / \mathrm{T}$ graph gave $\mathrm{q}_{\mathrm{st}} /$ $\mathrm{R}$ value (Eq (10)). The change of the isosteric heat of adsorption of zeolite 13X-water pair by adsorbate loading is given in Fig. 7. The value of average isosteric heat of adsorption was found as $73.6 \mathrm{~kJ} /$ mol which is compatible with the values given in the related literature [11].

$\frac{\mathrm{d} \ln \mathrm{P}}{\mathrm{d}(-1 / \mathrm{T})}=-\frac{\Delta \mathrm{H}}{\mathrm{R}}=\frac{\mathrm{q}_{\mathrm{st}}}{\mathrm{R}}$

The change in adsorption capacity for different regeneration temperatures at constant adsorption temperature of $35^{\circ} \mathrm{C}$ is illustrated in Fig. 8. Type I isotherm was obtained for all adsorption and desorption temperatures. It was observed that the adsorption capacity increased from $22 \%(\mathrm{~kg} / \mathrm{kg})$ to $24 \%(\mathrm{~kg} / \mathrm{kg})$ at adsorptive

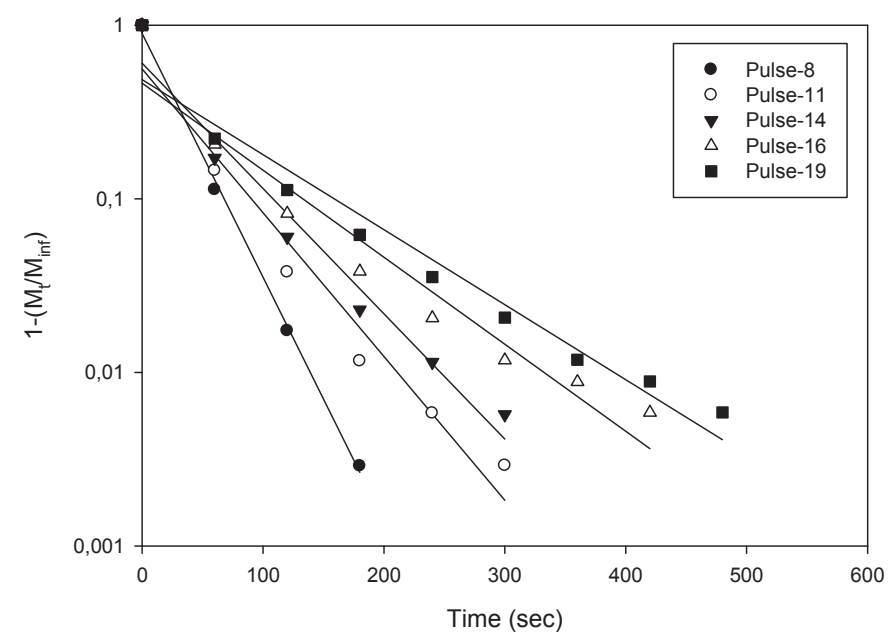

Fig. 10. Representative uptake curve of zeolite $13 \mathrm{X}$-water pair at logarithmic scale ( $\mathrm{T}_{\text {ads }}: 35^{\circ} \mathrm{C}$, constant initial adsorptive pressure: $2000 \mathrm{~Pa}, \mathrm{~T}_{\mathrm{reg}}: 90^{\circ} \mathrm{C}$ ).

pressure of $1000 \mathrm{~Pa}$ when the regeneration temperature increased from $90{ }^{\circ} \mathrm{C}$ to $150{ }^{\circ} \mathrm{C}$ (see also Table 3). The difference between the isotherms is due to the initial water concentration in zeolite $13 \mathrm{X}$ at beginning of the impulses. One reason for difference among the reported isotherms of the same adsorbent-adsorbate pair in the performed studies could be due to the different regeneration conditions such as regeneration temperature, vacuum level (pressure) and regeneration period. Thus, for a suggested isotherm in literature the regeneration conditions should be well known.

Fig. 8 also presents the comparison of the isotherm for $35^{\circ} \mathrm{C}$ with reported ones in literature. As can be seen, the present obtained isotherms have good agreement with those reported with San and Lin [24] and Sun et al. [25].

\subsection{Adsorption kinetics of zeolite $13 X$-Water}

Fig. 9 is the representative uptake curve of zeolite $13 \mathrm{X}$-water pair for successive runs with the constant initial adsorptive

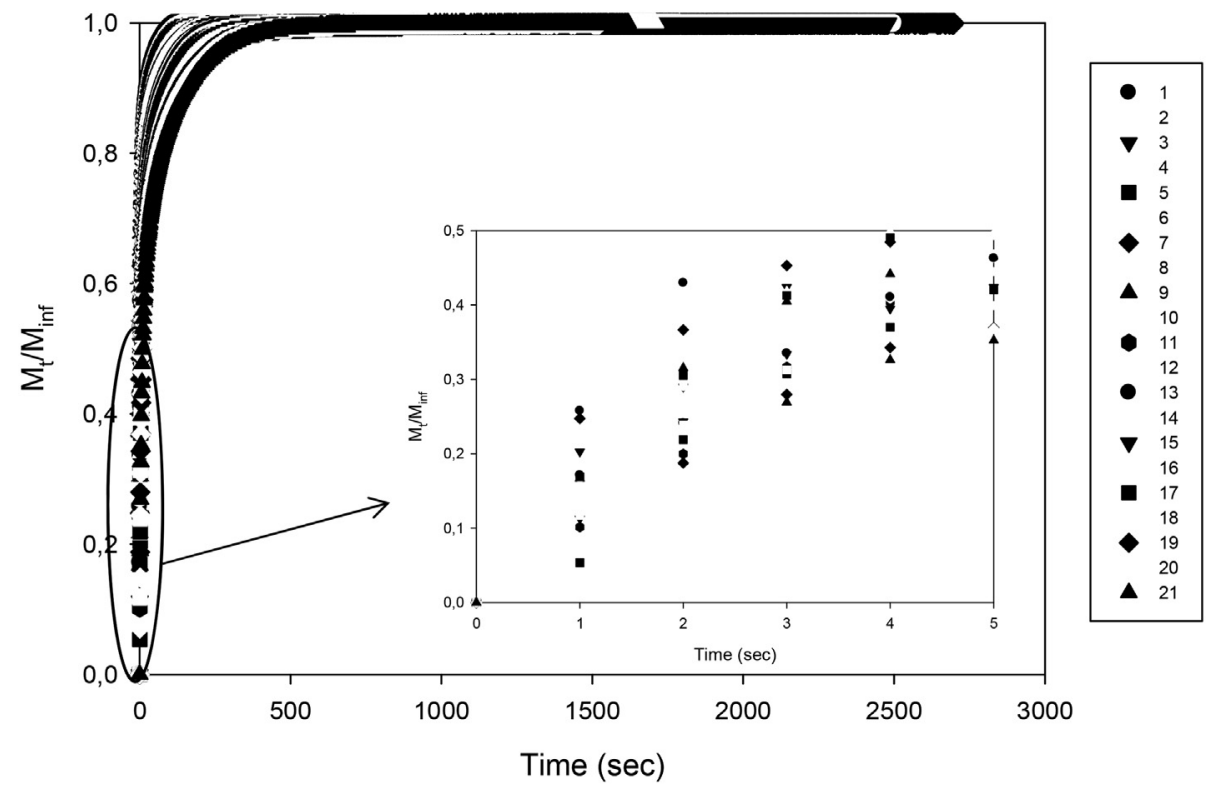

Fig. 9. Representative uptake curve of zeolite $13 \mathrm{X}$-water pair (Initial adsorptive pressure: $2000 \mathrm{~Pa}, \mathrm{~T}_{\text {ads }}: 35^{\circ} \mathrm{C} \mathrm{T}_{\mathrm{reg}}=120{ }^{\circ} \mathrm{C}$ ). 

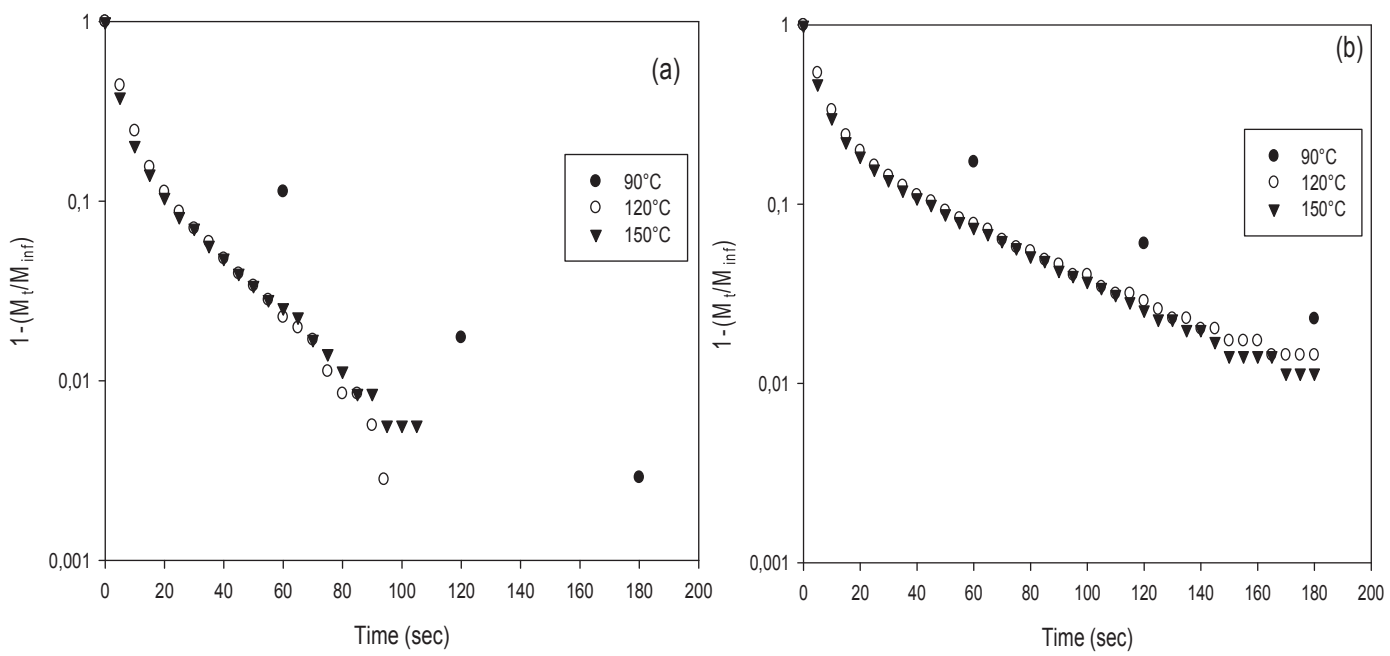

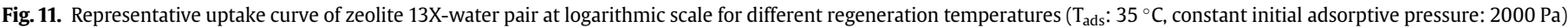
a)The 8 th pulse b) 14 th pulse.

concentration (pressure) of 2000 Pa for the regeneration temperature of $120^{\circ} \mathrm{C}$. The adsorption occurred very fast at the beginning of the adsorption runs. As can be seen from Fig. 9, even the data was collected with $1 \mathrm{~s}$ time interval, the data was not sufficient in order to calculate short term effective diffusivity $\left(\mathrm{m}_{\mathrm{t}} / \mathrm{m}_{\infty}<0.5\right)$. Thus, the determination of the mass diffusivity was performed only for the long time period.

By drawing the representative uptake curves at logarithmic scale (Fig. 10), the change of the controlling mechanism for successive runs can be observed $[5,26]$. Also the behavior of the runs were similar at the regeneration temperature of $120^{\circ} \mathrm{C}$ and $150{ }^{\circ} \mathrm{C}$ (Fig. 11), which may be related with the small difference between the amounts of the initial adsorbate concentration in the adsorbent (approximately $0.5 \mathrm{~kg} / \mathrm{kg}$ ) for these regeneration temperatures.

The effective mass diffusivity of the pair was calculated by using the analytical solutions of mass transfer equation (Eqs. (2) and (5)) for both infinite and finite systems. It was observed that the value of $\lambda$ in Eq. (5) was close to zero especially for high regeneration temperatures. Carman and Haul [21] indicated that when $\lambda$ is zero, adsorption behaves as sorption from an infinite extent in spite of having limited vapor volume. In the present study, the value of $\lambda$

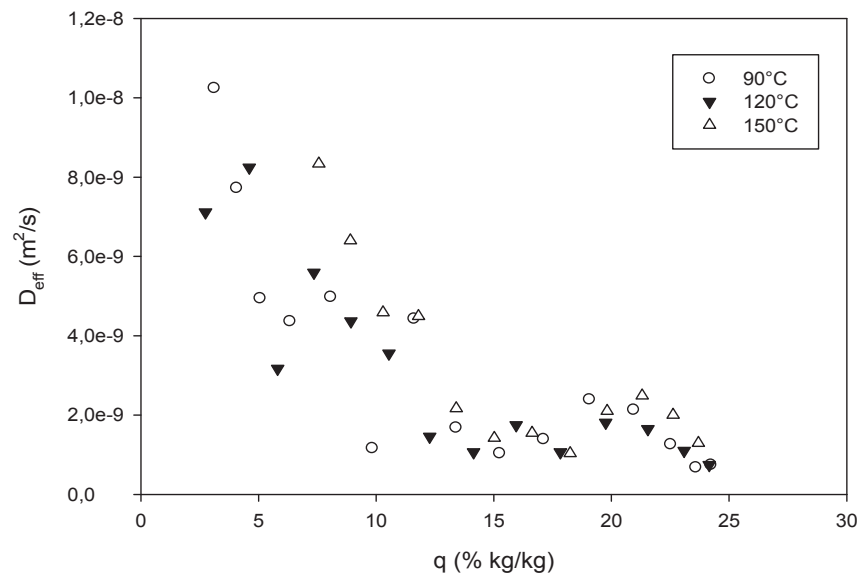

Fig. 12. Representative diagram for the change of effective diffusivity with adsorbate concentration at different regeneration temperatures (varying initial adsorptive pressure, $\mathrm{T}_{\text {ads }}: 35^{\circ} \mathrm{C}$ ) was smaller than 0.1, thus, all calculation for determination of long term mass diffusivity was performed based on Eq. (2) which is valid for the infinite extent.

The change in effective diffusivity with adsorbate concentration for different regeneration temperatures and different initial adsorptive pressure conditions for successive runs are given in Figs. 12 and 13. The change in the regeneration temperature did not have significant effect on the effective diffusivity in the long time period. It was observed that the effective diffusivity was in the range of $4 \times 10^{-9}-6 \times 10^{-8} \mathrm{~m}^{2} / \mathrm{s}$ and decreased with the increasing adsorbate concentration (see also Table 3). Although different adsorbent was used in the study, the order of magnitude of the effective diffusivity is comparable with the study of Beckert et al. [27] in which the effective diffusivity was decreased with time. The decrease of effective diffusivity may be due to the effect of heat transfer resistance, surface resistance or the hydration and migration of the cations in zeolite $13 \mathrm{X}$.

\section{Conclusion}

The adsorption equilibrium and mass diffusivity of zeolite 13X-water pair was determined for different adsorption and

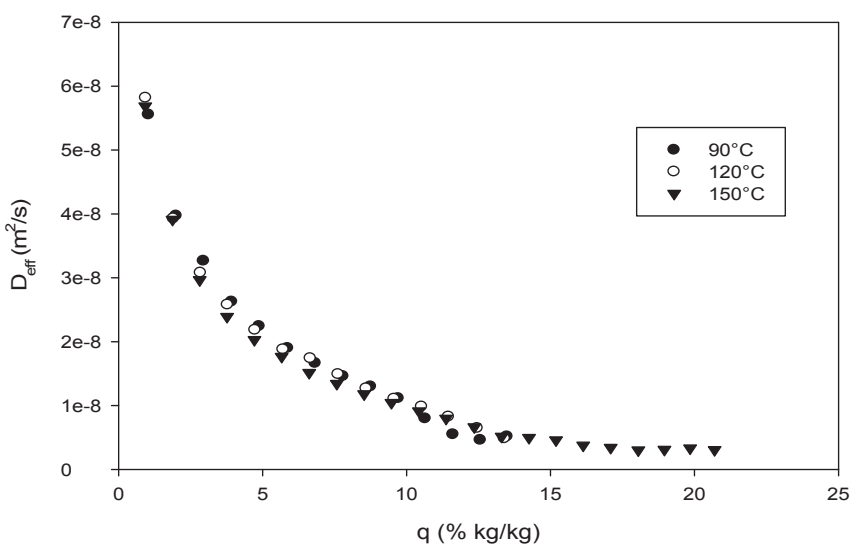

Fig. 13. Representative diagram for the change of effective diffusivity with adsorbate concentration at different regeneration temperatures (constant initial adsorptive pressure: $2000 \mathrm{~Pa}, \mathrm{~T}_{\mathrm{ads}}: 35^{\circ} \mathrm{C}$ ) 
regeneration temperatures. Type I isotherm was obtained for the zeolite 13X-water pair. The adsorption capacity increased with decreasing adsorption temperature at constant desorption temperature. As expected, the amount of adsorption increased with increasing regeneration temperature due to the effect of the initial adsorbate concentration in the adsorbent. Additionally, the effective diffusivity coefficient was calculated by using the long term analytical solution of mass transfer equation. The effective diffusivity of zeolite $13 \mathrm{X}$-water pair was found in the range of $4 \times 10^{-9}-6 \times 10^{-8} \mathrm{~m}^{2} / \mathrm{s}$ at $35^{\circ} \mathrm{C}$ for different regeneration temperatures at constant initial adsorptive pressure of $2000 \mathrm{~Pa}$ and it was observed that the effective diffusivity was affected by the change of initial adsorptive concentration for successive runs. Furthermore, there was a decrease with the increasing adsorbate loading which might have be arisen from surface resistance, heat transfer resistance and hydration and migration of the cations in zeolite $13 \mathrm{X}$. Consequently, the present study shows that the operating conditions such as regeneration temperature and initial adsorptive pressure have great influence on the adsorption kinetics.

\section{Acknowledgments}

This study was financially supported by Izmir Institute of Technology Scientific Research Projects Committee (Project number: 2012-IYTE-13).

\section{Nomenclature}

b

C

D

$\mathrm{D}_{\mathrm{c}}$

$D_{\text {eff }}$

$\mathrm{H}$

K

$\mathrm{m}$

$P$

$\mathrm{P}^{\text {sat }}$

$\mathrm{q}$

$\mathrm{q}_{\mathrm{m}}^{\mathrm{sat}}$

$\mathrm{q}_{\infty}$

$\bar{q}$

$\mathrm{q}_{\mathrm{st}}$

$r_{c}$

$\mathrm{R}_{\mathrm{p}}$

$\mathrm{T}$
Langmuir constant adsorptive concentration in fluid phase, $\mathrm{kg} \mathrm{kg}^{-1}$ diffusivity, $\mathrm{m}^{2} \mathrm{~s}^{-1}$ intracrystalline diffusivity, $\mathrm{m}^{2} \mathrm{~s}^{-1}$ intracrystalline diffusivity, $\mathrm{m}^{2} \mathrm{~s}^{-1}$ enthalpy, kJ mole ${ }^{-1}$ Henry's law constant mass of dry adsorbent, $\mathrm{kg}$ pressure, Pa saturation pressure, $\mathrm{Pa}$ adsorbed amount, $\mathrm{kg} \mathrm{kg}^{-1}$ saturation capacity, $\mathrm{kg} \mathrm{kg}^{-1}$ amount of adsorbed at equilibrium, $\mathrm{kg} \mathrm{kg}^{-1}$ average adsorbate concentration, $\mathrm{kg} \mathrm{kg}^{-1}$ isosteric heat of adsorption, $\mathrm{kJ} \mathrm{kg}^{-1}$ crystal radius, $\mathrm{m}$ particle radius, $\mathrm{m}$ temperature, ${ }^{\circ} \mathrm{C}$ or $\mathrm{K}$
Greek letters

$\Delta \mathrm{H} \quad$ heat of adsorption, $\mathrm{kJ} \mathrm{kg}^{-1}$

$\lambda$ fraction of the adsorbate added in the step
Subscripts

ads adsorption

eff effective

eq equilibrium

i initial

reg regeneration

sat saturation

$\infty \quad$ infinite

\section{References}

[1] J. Gülen, F. Zorbay, S. Arslan, Karaelmas Sci. Eng. J. 2 (1) (2012) 63-68.

[2] S.F. Özkan, in: Kimya Mühendisliği, Ege Üniversitesi, İzmir, 1996.

[3] F. Özkan, S. Ülkü, in: 11. Ulusal Isı Bilimi Ve Tekniği Kongresi, 1997, pp. 43-52. Edirne.

[4] J. Karger, D.M. Ruthven, Diffusion in Zeolites and Other Microporous Solids, John Wiley \& Sons, 1992.

[5] D.M. Ruthven, Microporous Mesoporous Mater. 162 (2012) 69-79.

[6] H. Yucel, D.M. Ruthven, J. Colloid Interface Sci. 74 (1) (1980) 186-195.

[7] G.V. Tsistsishvili, T.G. Andronikashvili, G.N. Kirov, L.D. Filizova, Natural Zeolites, Ellis Horwood Limited, England, 1992.

[8] S. Ülkü, S. Beba, Z. Kıvrak, B. Seyrek, Isı Bilim ve Tek. 8 (4) (1986) 23-28.

[9] S. Ülkü, Z. Kıvrak, M. Mobedi, Drying 86 (1986) 807-812.

[10] A. Jentys, G. Warecka, M. Derewinski, J.A. Lercher, J. Phys. Chem. 93 (12) (1989) 4837-4843.

[11] S. Ülkü, M. Mobedi, Energy Storage Syst. (1989) 487-507.

[12] R. Zhu, B. Han, M. Lin, Y. Yu, in: International Refrigeration and Air Conditioning Conference, 1990.

[13] Y.K. Ryu, S.J. Lee, J.W. Kim, C.H. Lee, Korean J. Chem. Eng. 18 (4) (2001) $525-530$.

[14] J.H. Kim, C.H. Lee, W.S. Kim, J.K. Suh, J.M. Lee, J. Chem. Eng. Data 48 (1) (2003) 137-141.

[15] A. Gorbach, M. Stegmaier, G. Eigenberger, Adsorption 10 (2004) 29-46.

[16] A. Di Lella, N. Desbiens, A. Boutin, I. Demachy, P. Ungerer, J.P. Bellat, A.H. Fuchs, Phys. Chem. Chem. Phys. 8 (46) (2006) 5396-5406.

[17] Y. Wang, M.D. Levan, J. Chem. Eng. Data 54 (10) (2009) 2839-2844.

[18] D.M. Ruthven, L. Heinke, J. Karger, Microporous Mesoporous Mater. 132 (1-2) (2010) 94-102.

[19] F. Cakicioglu-Ozkan, S. Ulku, J. Therm. Analysis Calorim. 94 (3) (2008) 699-702.

[20] G.E. Boyd, A.W. Adamson, L.S. Myers, Kinet. Ion Exch. Sorption Process. 69 (1947) 2836-2848.

[21] P.C. Carman, R.A.W. Haul, Proc. Royal Soc. London. Ser A Math. Phy. Sci. 222 (1954) 109-118.

[22] D.L. Bish, Clays Clay Min. 32 (1984) 444-452.

[23] T. Leppajarvi, I. Malinen, J. Kangas, J. Tanskanen, Chem. Eng. Sci. 69 (1) (2012) 503-513.

[24] J.Y. San, W.M. Lin, Appl. Therm. Eng. 28 (8-9) (2008) 988-997.

[25] L.M. Sun, N. Benamar, F. Meunier, Heat Recovery Syst. Chp 15 (1) (1995) 19-29.

[26] X.Y. Hu, E. Mangano, D. Friedrich, H. Ahn, S. Brandani, Adsorpt. J. Int. Adsorpt. Soc. 20 (1) (2014) 121-135.

[27] S. Beckert, F. Stallmach, H. Toufar, D. Freude, J. Kärger, Jürgen Haase, J. Phys. Chem. C 117 (47) (2013) 24866-24872. 